\title{
Noninvasive measures of venous ulcer recurrence prevention: integrative review
}

Medidas não invasivas de prevenção da recidiva de úlcera venosa: revisão integrativa Medidas no invasivas de prevención de la recidiva de úlcera venosa: revisión integrativa

Francielle Janaina de Souza ${ }^{1}$, Juliana Fonseca Santos Tomaz de Aquino ${ }^{1}$, Mirian Alves Guimarães Silva', Míryam Ferreira de Oliveira ${ }^{1}$, Sônia Regina Pérez Evangelista Dantas ${ }^{1, *}$

\section{ORCID IDS}

Souza FJ (D) https://orcid.org/0000-0002-3586-9174 Aquino JFST (D) https://orcid.org/0000-0002-0987-4156 Silva MAG (D) https://orcid.org/0000-0003-4573-5652 Oliveira MF (iD https://orcid.org/0000-0002-9336-5230 Dantas SRPE (iD https://orcid.org/0000-0002-9639-8900

\section{HOW TO CITE}

Souza FJ, Aquino JFST, Silva MAG, Oliveira MF, Dantas SRPE. Noninvasive measures of venous ulcer recurrence prevention: integrative review. ESTIMA, Braz. J. Enterostomal Ther., 17: e1119. https://doi.org/10.30886/estima.v17.713_IN

\begin{abstract}
Objective: This study aimed to identify, in the literature, noninvasive measures for prevention of venous ulcer recurrence (VUs). Methods: An integrative review was carried out in the databases of the Biblioteca Virtual em Saúde (BVS), Public Medline (PubMed), Cumulative Index of Nursing and Allied Health Literature (CINAHL) and Excerpta Medica Database (Embase) in the period from 2015 to 2017. the search was performed using the controlled descriptors «varicose ulcer» and «recurrence» and the Boolean operator AND between them in all databases described, in Portuguese, English, and Spanish. After the searches, two reviewers carried out the pre-selection by titles and summary of the articles followed by the full reading of the pre-selected studies. Results: 210 studies were identified, of which 188 were excluded because they did not attend to the guiding question. Two reviewers read in full the 22 pre-selected articles and included in this review nine that were part of the discussion of this paper. Conclusion: Studies in this review suggest that adherence and correct use of compressive therapy with socks associated with education and self-care measures are effective in preventing recurrence of $\mathrm{VU}$. The association of acetylsalicylic acid with standard measures of treatment still lacks conclusive results and new studies to prove efficacy are suggested.
\end{abstract}

DESCRIPTORS: Varicose ulcer. Relapse. Stomatherapy. Venous Insufficiency. Nursing care.

\footnotetext{
1.Universidade Estadual de Campinas - Faculdade de Enfermagem - Curso de Especialização de Enfermagem em Estomaterapia Campinas/SP - Brasil.
}

*Autor correspondente: srpedantas@gmail.com

Recebido: 13 Fev 2019 | Aceito: 28 Maio 2019 


\section{RESUMO}

Objetivo: Este estudo teve como objetivo identificar, na literatura, as medidas não invasivas de prevenção da recidiva de úlceras venosas (UVS). Método: Realizou-se revisão integrativa nas bases de dados da Biblioteca Virtual em Saúde (BVS), Public Medline (PubMed), Cumulative Index of Nursing and Allied Health Literature (CINAHL) e Excerpta Medica dataBASE (Embase) no período de 2015 a 2017. A busca bibliográfica foi realizada utilizando-se os descritores controlados "varicose ulcer" e "recurrence" e o operador booleano AND entre eles em todas as bases de dados descritas, em português, inglês e espanhol. Após as buscas, dois revisores realizaram a pré-seleção por títulos e resumo dos artigos seguida da leitura na íntegra dos estudos pré-selecionados. Resultado: Identificaram-se 210 estudos, sendo que 188 foram excluídos por não atenderem à questão norteadora. Dois revisores leram na íntegra os 22 artigos pré-selecionados e incluíram nesta revisão nove que fizeram parte da discussão deste trabalho. Conclusão: Os estudos desta revisão sugerem que a adesão e o uso correto da terapia compressiva com meias associados a medidas de educação e autocuidado são efetivos para prevenção de recidiva da UV. A associação de ácido acetilsalicílico com as medidas padrão de tratamento ainda carece de resultados conclusivos e sugerem-se novos estudos para comprovação da eficácia.

DESCRITORES: Úlcera varicosa. Recidiva. Estomaterapia. Insuficiência venosa. Cuidados de enfermagem.

\section{RESUMEN}

Objetivo: Este estudio tuvo como objetivo identificar, en la literatura, las medidas no invasivas de prevención de la recidiva de úlceras venosas (UVs). Método: Se realizó una revisión integrativa en las bases de datos de la Biblioteca Virtual em Saúde (BVS), Public Medline (PubMed), Cumulative Index of Nursing and Allied Health Literature (CINAHL) y Excerpta Medica Database (Embase) en el período de 2015 a 2017. La búsqueda bibliográfica se realizó a través de descriptores controlados "úlcera varicosa" y "recurrencia" y el operador booleano AND entre ellos en todas las bases de datos descritas en Portugués, Inglés y Español. Después de las búsquedas, dos revisores realizaron la preselección por títulos y resumen de los artículos seguida de la lectura íntegra de los estudios preseleccionados. Resultado: Se identificaron 210 estudios, siendo que 188 fueron excluidos por no atender a la cuestión orientadora. Dos revisores leyeron en su totalidad los 22 artículos preseleccionados e incluyeron en esta revisión nueve que formaron parte de la discusión de este trabajo. Conclusión: Los estudios de esta revisión sugieren que la adhesión y el uso correcto de la terapia compresiva con medias asociadas a medidas de educación y autocuidado son efectivas para prevenir la recidiva de la UV. La asociación de ácido acetilsalicílico con las medidas estándar de tratamiento todavía carece de resultados concluyentes y se sugieren nuevos estudios para comprobar la eficacia.

DESCRIPTORES: Úlcera varicosa. Recaída. Estomaterapia. Insuficiencia venosa. Cuidados de enfermería.

\section{INTRODUCTION}

Ulcers due to venous insufficiency (VUs) account for $75 \%$ of chronic ulcers of the lower limbs and affect approximately $1 \%$ of the world population, with an increase in prevalence to $2 \%$ in the population over 80 years old, is characterized as a global public health problem ${ }^{1-5}$.

VU has a negative impact on the quality of life (QoL), self-esteem and functionality, causing pain, loss of mobility, withdrawal, and restriction of activities of professional and social life and leisure ${ }^{4}$.

The healing rate in six months can vary from 45 to $70 \%$, depending on the evaluation and therapeutic conducts, with a significant difference if performed by specialists or general practitioners. The 12 -month relapse rate may range from 26 to $69 \%$. The cost of treating a person with VU is high and varies according to the countryss economic and health structure, ranging from $£ 168$ to $£ 198$ million annually in the UK and $€$ 9,569 per client with an ulcer in Germany ${ }^{5}$.
In Brazil, epidemiological records of prevalence and incidence of VU are still scarce and, to date, there are no official national data. A prevalence study conducted in the city of Botucatu, state of São Paulo, with a population of 1,755 patients, found $1.5 \%$ of cases of active or healed $\mathrm{VU}^{6}$.

Large numbers of people with VU in our country are treated in Atenção Básica da Saúde-ABS (Primary Health Care) and treatment is mostly curative, not contemplating health promotion measures and prevention of relapses. The early use of compressive therapy is described as a factor preventing the chronicity of acute wounds in lower limbs and this time is defined in up to two weeks ${ }^{7}$. However, we still lack guidelines for the early diagnosis and care of people with chronic venous insufficiency (CVI) and VUs as one of the priority lines of care for chronic diseases in ABS.

Venous hypertension is the main cause of CVI and the clinical, etiological, anatomical and pathophysiological 
classification system (CEAP) is a useful tool for stratification of people with the disease, helping to standardize diagnosis and severity. Although CEAP cannot be used as a marker of treatment progression, it can be a useful tool to guide the referral need for specialized care ${ }^{7}$.

The standard treatment of VU is very well established and consists essentially of compressive limb therapy and topical ulcer therapy ${ }^{8}$. Today, we have a wide variety of bandages, socks, and equipment for therapeutic compression, as well as numerous technologies for topical treatment of the wound during the process of tissue repair ${ }^{8-10}$. However, despite the knowledge and technological resources to treat these ulcers, relapse is one of the greatest challenges in this population, and measures to promote health and maintain compressive therapy are essential for its prevention ${ }^{3,9}$.

About $30 \%$ of healed ulcers can reopen in the first year and this rate can reach $78 \%$ after two years, causing significant personal, social and economic impact ${ }^{11}$.

The main factor related to relapses is the lack of adherence to prevention measures related to changes in lifestyle and use of compressive therapy, due to lack of knowledge and lack of adequate guidance or neglect ${ }^{3}$. Adherence to the therapeutic plan has been shown to be one of the main factors for the reduction of healing time and prevention of ulcer recurrence ${ }^{1}$.

Aiming to contribute to the knowledge about the recurrence of VUs, this study seeks to identify in the literature, the noninvasive prevention measures in order to minimize their recurrence.

\section{METHODS}

An integrative literature review was conducted as a method of searching and synthesizing evidence for its ability to gather and synthesize relevant information from studies with different methodological designs, providing a critical and comprehensive assessment of the subject in question, in order to support the practice evidence-based clinic and point out gaps. This review was developed and described in six methodological steps, according to Mendes et al. ${ }^{12}$.

Considering the first stage of the research, the present work was guided by the following guiding question: what are the non-invasive therapeutic measures to prevent VU recurrence?

In the second stage, the data collection was done by means of a bibliographical survey of publications indexed or cataloged in the portals Biblioteca Virtual em Saúde (BVS) and Public Medline (PubMed) and Cumulative Index of Nursing and Allied Health Literature databases ( CINAHL) and Excerpta Medica Database (Embase) (Fig. 1).

The bibliographic search was performed using the controlled descriptors «varicose ulcer» and «recurrence»

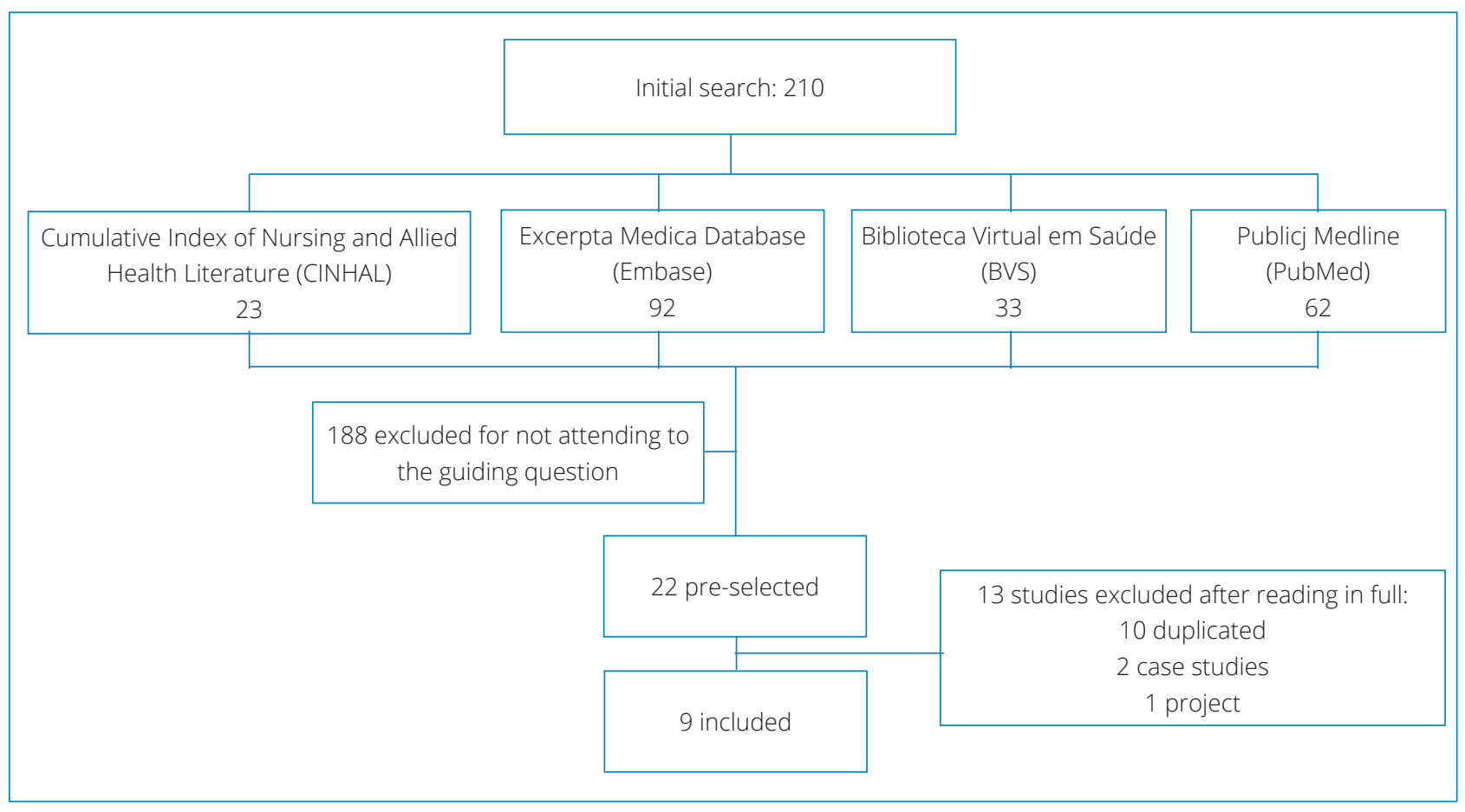

Figure 1. Flowchart of the selection process of the studies included in the integrative review. 
and the Boolean operator AND between them in all databases described. Terms used for the search were selected in the Medical Subject Headings (MeSH) as $\mathrm{MeSH}$ terms and All Fields, and in the Descritores em Ciências da Saúde (DeCS) as descriptors and keywords.

The following inclusion criteria were established in the review: articles published in the period 2015 to 2017 , in the Portuguese, Spanish and English languages, and whose titles and/or summaries covered aspects related to recurrence of VU in humans and were fully available in the Sistema de Biblioteca da Universidade Estadual de Campinas-SBU (System of Library of the Universidade Estadual de Campinas). We excluded studies with duplicate publications that did not address the relevant theme in relation to the study objective and case studies.

After the searches, two reviewers performed the preselection by titles and summary of the articles followed by the full reading of the pre-selected studies according to the guiding question and evaluation of those who responded to the inclusion criteria of this study.

In the third stage, the data were synthesized according to the research objectives and categorized with information extracted from the selected studies: year, title, language, type, and objective of the study, result/recommendation. In the fourth step, the results were described in descriptive form and demonstrated in figures and tables. In the fifth stage, the discussion and interpretation of the results were carried out.

In the last step, the synthesis document and the presentation of this revision were constructed.

\section{RESULTS}

Through the search strategy, 210 studies were identified, of which 188 were excluded because they did not attend to the guiding question. Two reviewers read in full the 22 pre-selected articles and included in this review nine that were part of the discussion of this paper.

Figure 1 summarizes how the selection process of the studies took place.

Table 1 shows the data on the nine articles included in this review.

Table 1. Summary of selected articles.

\begin{tabular}{|c|c|c|c|c|}
\hline $\begin{array}{c}\text { Year; } \\
\text { Language }\end{array}$ & Title & $\begin{array}{l}\text { Kind of } \\
\text { study }\end{array}$ & Purpose of the study & Result/Recomendation \\
\hline $\begin{array}{l}\text { 2015; } \\
\text { English }\end{array}$ & $\begin{array}{l}\text { Identifying risk factors } \\
\text { and protective factors } \\
\text { for venous leg ulcer } \\
\text { recurrence using a } \\
\text { theoretical approach: A } \\
\text { longitudinal study }\end{array}$ & Longitudinal & $\begin{array}{l}\text { Identify risk and protective } \\
\text { factors for venous ulcer } \\
\text { recurrence }(\mathrm{VU}) \text {. }\end{array}$ & $\begin{array}{l}\text { Four significant risk factors for ulcer recurrence were } \\
\text { identified: age, history of deep venous thrombosis, history } \\
\text { of anterior leg ulcer and total duration of ulcer. Significant } \\
\text { protective factors included elevation of the legs for } 30 \\
\text { minutes per day and higher levels of physical activity. }\end{array}$ \\
\hline $\begin{array}{l}\text { 2015; } \\
\text { English }\end{array}$ & $\begin{array}{l}\text { The experience of self- } \\
\text { management following } \\
\text { venous leg ulcer } \\
\text { healing }\end{array}$ & $\begin{array}{l}\text { Exploratory } \\
\text { qualitative }\end{array}$ & $\begin{array}{l}\text { To explore the experiences } \\
\text { of self-management of the } \\
\text { elderly after } V U \text { healing, } \\
\text { considering the impact of an } \\
\text { education package related to } \\
\text { recurrence risks. }\end{array}$ & $\begin{array}{l}\text { Participation in a standardized education program prior } \\
\text { to ulcer healing proved to be effective in establishing self- } \\
\text { management strategies and adherence to VU recurrence } \\
\text { prevention measures. }\end{array}$ \\
\hline $\begin{array}{l}\text { 2016; } \\
\text { English }\end{array}$ & $\begin{array}{l}\text { Compression for } \\
\text { primary prevention, } \\
\text { treatment, and } \\
\text { prevention of } \\
\text { recurrence of venous } \\
\text { leg ulcers: an evidence- } \\
\text { and consensus-based } \\
\text { algorithm for care } \\
\text { across the continuum }\end{array}$ & $\begin{array}{l}\text { Systematic } \\
\text { review and } \\
\text { consensus } \\
\text { building }\end{array}$ & $\begin{array}{l}\text { Develop an algorithm based } \\
\text { on evidence and expert } \\
\text { consensus for primary } \\
\text { compression, treatment and } \\
\text { prevention of } V U \text { relapse. }\end{array}$ & $\begin{array}{l}\text { The compression algorithm for chronic venous insufficiency } \\
(\mathrm{CVI}) \text { is based on anamnesis, physical examination, brachial } \\
\text { ankle index (ABI), exclusion of other diseases and wound } \\
\text { etiologies and uses the clinical, etiological, anatomical } \\
\text { and pathophysiological classification system (CEAP ) to } \\
\text { determine the severity of venous insufficiency and to adjust } \\
\text { the compressive therapy (type and class of compression), } \\
\text { as well as the necessity or not of the pharmacological } \\
\text { treatment. }\end{array}$ \\
\hline
\end{tabular}


Table 1. Continuation...

\begin{tabular}{|c|c|c|c|c|}
\hline $\begin{array}{c}\text { Year; } \\
\text { Language }\end{array}$ & Title & $\begin{array}{l}\text { Type of } \\
\text { study }\end{array}$ & Objective of the study & Result/Recomendation \\
\hline $\begin{array}{l}\text { 2016; } \\
\text { English }\end{array}$ & $\begin{array}{l}\text { Interventions for } \\
\text { helping people adhere } \\
\text { to compression } \\
\text { treatments for venous } \\
\text { leg ulceration }\end{array}$ & $\begin{array}{l}\text { Systematic } \\
\text { review }\end{array}$ & $\begin{array}{l}\text { To evaluate the benefits and } \\
\text { damages of interventions } \\
\text { aimed at stimulating people } \\
\text { to join compressive therapy, } \\
\text { both in the treatment of } \\
\text { ulcer and in the prevention of } \\
\text { relapse. }\end{array}$ & $\begin{array}{l}\text { Assays for adherence to compressive therapy are scarce } \\
\text { and of poor quality due to the risk of bias of selection } \\
\text { and imprecision, not allowing clarity in the results of the } \\
\text { interventions. }\end{array}$ \\
\hline $\begin{array}{l}\text { 2016; } \\
\text { English }\end{array}$ & $\begin{array}{l}\text { Oral aspirin for treating } \\
\text { venous leg ulcers }{ }^{17}\end{array}$ & $\begin{array}{l}\text { Systematic } \\
\text { review }\end{array}$ & $\begin{array}{l}\text { To evaluate the benefits and } \\
\text { damages of oral aspirin in } \\
\text { the healing and recurrence } \\
\text { of VUs. }\end{array}$ & $\begin{array}{l}\text { Assays for adherence to compressive therapy are scarce } \\
\text { and of poor quality due to the risk of bias of selection } \\
\text { and imprecision, not allowing clarity in the results of the } \\
\text { interventions. }\end{array}$ \\
\hline $\begin{array}{l}\text { 2016; } \\
\text { Portuguese }\end{array}$ & $\begin{array}{l}\text { Prevention of varicose } \\
\text { ulcer relapse: a cohort } \\
\text { study }{ }^{3}\end{array}$ & Longitudinal & $\begin{array}{l}\text { To determine the rate of } \\
\text { recurrence of varicose ulcers } \\
\text { and to verify the association } \\
\text { between relapse and } \\
\text { prevention measures adopted. }\end{array}$ & $\begin{array}{l}\text { The rate of ulcer recurrence was high and the main } \\
\text { prevention measures were compression stocking, resting } \\
\text { and use of moisturizing cream. The use of one of these } \\
\text { measures alone did not produce the desired result. }\end{array}$ \\
\hline $\begin{array}{l}\text { 2016; } \\
\text { English }\end{array}$ & $\begin{array}{l}\text { Subjective and } \\
\text { objective assessment } \\
\text { of patients> } \\
\text { compression therapy } \\
\text { skills as a predicator of } \\
\text { ulcer recurrence }^{18}\end{array}$ & Longitudinal & $\begin{array}{l}\text { Objectively and objectively } \\
\text { assess clients' abilities to use } \\
\text { compression therapy as a } \\
\text { predictor of ulcer recurrence. }\end{array}$ & $\begin{array}{l}\text { The development of skills for compression therapy by } \\
\text { clients is the key element of a nurse-led prevention } \\
\text { program, representing the most significant modifiable risk } \\
\text { factor for recurrent ulcers. Although the development of } \\
\text { compression skills is undeniably important, other factors } \\
\text { should be considered, such as, for example, surgical } \\
\text { correction of superficial reflux. }\end{array}$ \\
\hline $\begin{array}{l}\text { 2016; } \\
\text { English }\end{array}$ & $\begin{array}{l}\text { Whatıs new: } \\
\text { management of } \\
\text { venous leg ulcers: } \\
\text { treating venous leg } \\
\text { ulcers }^{19}\end{array}$ & $\begin{array}{l}\text { Integrative } \\
\text { review }\end{array}$ & $\begin{array}{l}\text { Outline the ideal management } \\
\text { for people with VUs, } \\
\text { highlighting the role of a } \\
\text { multidisciplinary team. }\end{array}$ & $\begin{array}{l}\text { Long-term compression therapy with socks or surgical } \\
\text { intervention reduces the incidence of VU recurrence. }\end{array}$ \\
\hline $\begin{array}{l}\text { 2017; } \\
\text { English }\end{array}$ & $\begin{array}{l}\text { The effect of a patient } \\
\text { education intervention } \\
\text { on knowledge } \\
\text { and recurrence of } \\
\text { venous ulcer: results } \\
\text { of a prospective } \\
\text { intervention and } \\
\text { retrospective analysis }{ }^{20}\end{array}$ & Longitudinal & $\begin{array}{l}\text { Examine the effectiveness } \\
\text { of a client's home education } \\
\text { program on disease } \\
\text { awareness and self-care and } \\
\text { VU recurrence rates. }\end{array}$ & $\begin{array}{l}\text { Client education improves scores on disease knowledge } \\
\text { and self-care and can reduce VU recurrence rates. }\end{array}$ \\
\hline
\end{tabular}

\section{DISCUSSION}

Of the studies selected in this review, we have two published in $2015^{13,14}$, six in $2016^{3,15-19}$ and one in $2017^{20}$, suggesting that the subject has been the object of recent investigations. Regarding the kind of study, there were four longitudinal ${ }^{3,13,18,20}$, an exploratory qualitative ${ }^{14}$, three systematic reviews ${ }^{16,17,19}$ and an article on medical education based on an integrative review and expert opinion $^{15}$. Most of the works selected in the search bases were available in English ${ }^{13-20}$; no publications were found in the Spanish language and only one in Portuguese ${ }^{3}$. This result suggests that the scientific production on VU recurrence in Brazil still lacks research.

In the studies, it was possible to identify that the noninvasive therapeutic measures for the prevention of recurrence of $\mathrm{VU}$ are composed of three different forms of treatments and care: compressive therapy ${ }^{3,15,16,18,19}$, education, and self care ${ }^{13,14,20}$ and anticoagulation with acetylsalicylic acid ${ }^{17}$. To facilitate the presentation and 
organization of the results, we will discuss each theme separately.

\section{Compressive therapy}

Therapeutic compression is the oldest and most widely used intervention for VU therapy. When indicated and used correctly, it is the gold standard of treatment, significantly improving healing rates in VU clients and reducing the likelihood of their recurrence $e^{2,3-5,9,10,15,16,18}$. A systematic review conducted in 2014 to evaluate the effect of compressive therapy on the prevention of VU relapse selected four randomized controlled trials (979 participants), all using compression stockings. In this study, no primary studies with compressive bandages to prevent VU recurrence were found. The findings have shown that there is evidence that compression stockings reduce VU relapse rates in comparison to no compression. The results of one of the studies suggest that the recurrence is lower with the use of high compression socks than with average compression socks in three years, while another study found no difference in five years. Rates of intolerance of the use of compression stockings were high and there is insufficient evidence to aid in the selection of different types, brands or lengths of compression stockings ${ }^{21}$.

Borges et al. ${ }^{3}$, in a cohort study of 50 participants with post-healing VU, followed up for 10 years, observed a high recurrence rate $(62.2 \%)$, mostly in women, the elderly, illiterate and retired. As an effective measure in relapse prevention, the use of compression socks, moisturizing cream and resting were shown as an effective measure. This study corroborates the findings of Finlayson et al.. ${ }^{13}$, who found, as factors of VU relapse protection, the daily lifting of the legs for 30 minutes and higher levels of physical activity.

Harding et al. ${ }^{5}$ emphasize that despite evidence of compressive therapy as the "gold standard» for healing and prevention of VU recurrence, there are still failures in the individualized assessment and adequacy of the type of compression, lack of knowledge of the different compression systems available, their indications and contraindications, lack of skill or confidence in the application of therapy, resulting in suboptimal compression and lack of clear protocols and referral systems for complex cases requiring specialized assessment and conduct.
The Wound Ostomy and Continence Nurses Society (WOCN)10developed an evidence-based consensus, establishing compression algorithms for primary prevention, treatment, and prevention of recurrent ulcers in people with CVI. The algorithm is based on clinical evaluation, through its health history and physical examination of the lower limbs. Once the CVI is established, CEAP ( 0 to 6 ) is used to determine the severity of the disease and to establish the therapeutic course. For people with CVI and CEAP 0 , an educational program should be established, emphasizing factors that promote health, minimize disease, and influence QoL; for CEAP 1-2, the need for compression is established based on the symptoms (weight, pain, burning and pruritus in the leg); for CEAP 3-4, the determination of the type and level of compression is established based on the brachial-ankle index (ABI); and in CEAP 5-6, in addition to the appropriateness of ABI-based therapeutic compression, individuals with signs of associated arterial disease $(A B I \leq 0.5$ or $\geq 1.3$ ) should be referred to the specialist for further examination and assessment of the need for the use of pentoxifylline and topical steroids for the treatment of eczema or dermatitis. Regardless of the CEAP classification, client and family/caregiver education is essential for knowledge of risks, health promotion measures, prevention of complications and adherence to the self-care process 10,13-15,20. Alavi et al.19emphasize the role of a multidisciplinary team for quality care and emphasize that long-term compressive therapy with socks or surgical intervention reduces the incidence of VU recurrence.

\section{Education for self-care}

Education for self-care involves individualized actions of teaching-learning to the client and family/caregiver, based on established needs and risks, with the aim of preserving health and/or preventing the disease. Understanding CVI, risk factors for ulceration, and therapeutic approaches based on limb compression may be facilitators for treatment engagement and prevention of $\mathrm{VU}$ recurrence ${ }^{13,14,20}$. In this context, the training and the systematic evaluation of the use of therapeutic compression are also essential elements for therapeutic efficacy ${ }^{20}$.

It is noteworthy that, in the databases of this review, there are few Brazilian studies that address teachinglearning issues as a strategy to prevent $\mathrm{VU}$ recurrence. 
Since in Brazil the majority of this population is assisted in the basic health network, it is considered fundamental the investment in this area of research.

Edwards et al. ${ }^{22}$, in a randomized, controlled study of 56 patients, the effectiveness of VU healing and pain minimization of a community nursing care program was investigated by comparing two groups, both with 28 people with VU. The study group received educational information from the program and standard treatment, and the control group only standard treatment at home. Both were followed up for 12 weeks. The activities of the study group involved education, counseling, clinical support, social interaction, and setting goals for functional and social activities. The control group received evaluations and home health treatments (ABI, referral for vascular evaluation if necessary, standard ulcer treatment, care based on the client's needs and clarification about VU).

In the study group, was observed significant reductions in mean pain scores $(p=0.004)$, the degree to which pain affected sleep $(\mathrm{p}=0.003)$, and ulcer healing rates $(46.2 \%$ vs. $25.9 \% \%)$ and in the scoring scores of the healing $(\mathrm{p}=0.002)^{22}$.

Gonzalez ${ }^{20}$ conducted a prospective-retrospective case-control study to evaluate the effectiveness of a home-based client education program involving disease awareness and self-care and the impact on VU recurrence rates. The intervention consisted of an individual presentation of 45 minutes at home, using audiovisual resources, a brochure and an explanatory brochure addressing the theme. Pre- and post-intervention knowledge was evaluated through a learning list that included two subscales to measure knowledge of the disease and knowledge of self-care activities. The study demonstrated that VU recurrence rates were lower in the study group when compared to the control group. The results of this study confirm that client education improves disease awareness scores and self-care and may reduce VU recurrence rates ${ }^{20}$. Kapp et al. ${ }^{14}$ also showed that the use of a program of e-learning used for elderly people with active ulcer informed successful self-management strategies to prevent recurrence of VU after healing. Moscicka et al. ${ }^{18}$ found that skills and knowledge about compressive therapy are modifiable and significant risk factors for the prevention of $\mathrm{VU}$ relapse.

\section{Anticoagulation with acetylsalicylic acid}

Acetylsalicylic acid is a non-steroidal anti-inflammatory with analgesic, antipyretic and anti-inflammatory properties. Its mechanism of action is based on the irreversible inhibition of the cyclooxygenase enzyme involved in the synthesis of prostaglandins. Acetylsalicylic acid inhibits platelet aggregation by blocking the synthesis of thromboxane A2 in platelets. For this reason, it is used in various indications related to the vascular system, usually in daily doses of 75 to $300 \mathrm{mg}^{23}$.

Carvalho et al. ${ }^{17}$, in a systematic review, included two clinical trials with acetylsalicylic acid (300 mg/day), compared with placebo given in people using compression therapy. The first was conducted in the United Kingdom ${ }^{24}$ (20 participants) and reported that daily administration of aspirin increased both the rate of improvement in healing (as measured by the reduction in VU size) and cure rate as compared to the placebo group over a four-month period. The study identified potential benefits of acetylsalicylic acid as an adjunct to compression, but the sample size was small and the mechanisms by which acetylsalicylic acid improved healing and its effects on VU recurrence were not investigated. The second study was carried out in Spain ${ }^{25}$ (51 participants) and compared the daily administration of acetylsalicylic acid $(300 \mathrm{mg})$ in people with VU and lower limb therapeutic compression with a control group that used the only compression during the five-month period. The mean healing time was shorter (12 weeks in the study group and 22 weeks in the control group). The mean recurrence time was higher in the study group (39 days versus 16.3 days). Data from this study are limited, considering sample size and population follow-up time. Low-quality evidence from these studies does not allow definitive conclusions about the benefits or harms of oral acetylsalicylic acid in the healing or recurrence of VU. Future studies should examine the efficacy of this type of combination in the treatment of VUs and relapse prevention.

\section{CONCLUSION}

Studies of this review suggest that adherence and correct use of compressive therapy with socks, associated with self-care measures such as physical activity, skin 
hydration, rest and leg elevation daily for 30 minutes, are effective in preventing VU relapse. Self-care education should consider the characteristics of the at-risk population and the skill and knowledge of the health team about severity, and therapeutic behaviors may influence the effectiveness of these actions. Regarding the association of acetylsalicylic acid with the standard measures of venous insufficiency treatment, there are still no conclusive results about its action in the prevention of relapse and new studies are suggested to prove its efficacy. Despite the importance of this theme for the adequacy of public health strategies, the number of publications is still incipient and requires national studies.

\section{AUTHORS' CONTRIBUTION}

Conceptualization, Souza FJ de, Aquino JFST de, Silva MAG, and Oliveira MF de; Methodology, Dantas SRPE; Writing first version, Souza FJ de, Aquino JFST de, Silva MAG, and Oliveira MF de; Writing - Reviewing and Editing, Dantas SRPE; Supervision, Dantas SRPE.

\section{REFERENCES}

1. Liberato SMD, Araújo RO, Souza AJG, Marconato AMP, Costa IKF, Torres GV. Adesão ao tratamento de pessoas com úlceras venosas atendidas na atenção primária à saúde. Aquichán. 2017;17(2):128-39. https://doi.org/10.5294/ aqui.2017.17.2.2

2. Nicolosi JT, Altran SC, Barragam JP, Carvalho VF, Isaac C. Terapias compressivas no tratamento de úlcera venosa: estudo bibliométrico. Aquichán. 2015;15(2);283-95. https:// doi.org/10.5294/aqui.2015.15.2.11

3. Borges EL, Ferraz AF, Carvalho DV, Matos SS, Lima VLAN. Prevenção de recidiva de úlcera varicosa: um estudo de coorte. Acta Paul Enferm. 2016;29(1):9-16. https://doi. org/10.1590/1982-0194201600003

4. Salome GM, Ferreira LM. Qualidade de vida em pacientes com úlcera venosa em terapia compressiva por bota de Unna. Rev Bras Cir Plást. 2012;27(3):466-71.

5. Harding K, Dowsett C, Fias L, Jelnes R, Mosti R, Õiem R, et al. Simplifying venous leg ulcer management. Consensus recommendations [Internet]. London: Wounds International; 2015 [cited 10 Feb 2018]. Available at: http://www.3mlearning. co.uk/media/1072/3m_14_4_consensus_web.pdf

6. Maffei FH, Magaldi C, Pinho SZ, Lastoria S, Pinho W, Yoshida $W B$, et al. Varicose veins and chronic venous insufficiency in Brazil: prevalence among 1755 inhabitants of a country town. Int J Epidemiol. 1986;15(2):210-7. https://doi. org/10.1093/ije/15.2.210

7. Fletcher F, Atkin L, Dowsett C, Hopkins A, Tickle J, Worboys $F$, et al. Best practice statement: holistic management of venous leg ulceration [Internet]. London: Wounds UK; 2016 [cited 01 May 2019]. Available at: www.wounds-uk.com

8. Sociedade Brasileira de Angiologia e de Cirurgia Vascular. Projeto diretrizes SBACV: insuficiência venosa crônica - Diagnóstico e tratamento [Internet]. Rio de Janeiro: SBACV; 2015 [cited 10 Feb 2018]. Available at: http://www.sbacv.org.br/lib/media/pdf/ diretrizes/insuficiencia-venosa-cronica.pdf

9. Fletcher J, Moffatt C, Partsch H, Vowden K, Vowden P. Principles of compression in venous disease: a practitioner's guide to treatment and prevention of venous leg ulcers [Internet]. London: Wounds International; 2013 [cited 12 May 2018]. Available at: www.woundsinternational.com
10. Fletcher J, Atkin L, Dowsett C, Gardner S, Schofield A, Staines $\mathrm{K}$, et al. Best practice statement: addressing complexities in the management of venous leg ulcers [Internet]. London: Wounds UK; 2019 [cited 04 May 2019]. Available at: www. wounds-uk.com

11. Abbade LPF, Lastoria S. Abordagem de pacientes com úlcera da perna de etiologia venosa. Rev Bras Dermatol. 2006;81(6):509-22. https://doi.org/10.1590/S036505962006000600002

12. Mendes KDS, Silveira RCCP, Galvão CM. Revisão integrativa: método de pesquisa para a incorporação de evidências na saúde e na enfermagem. Texto Contexto Enferm. 2008;17(4):758-64. https://doi.org/10.1590/S0104-07072008000400018

13. Finlayson K, Min-Lin W, Edwards HE. Identifying risk factors and protective factors for venous leg ulcer recurrence using a theoretical approach: a longitudinal study. Int J Nur Stud. 2015;52:1042-51. https://doi.org/10.1016/j. ijnurstu.2015.02.016

14. Kapp S, Miller C. The experience of self-management following venous leg ulcer healing. J Clin Nurs. 2015;24:13009. https://doi.org/10.1111/jocn.12730

15. Ratliff CR, Yates S, McNichol L, Gray M. Compression for primary prevention, treatment, and prevention of recurrence of venous leg ulcers: an evidence-and consensus-based algorithm for care across the continuum. J Wound Ostomy Continence Nurs. 2016;43(4):347-64. https://doi.org/10.1097/WON.0000000000000242

16. Weller CD, Buchbinder R, Johnston RV. Interventions for helping people adhere to compression treatments for venous leg ulceration. Cochrane Database Syst Rev. 2016;9(9):CD008378. https://doi.org/10.1002/14651858.CD008378.pub3

17. Carvalho PEO, Magolbo NG, De Aquino RF, Weller CD. Oral aspirin for treating venous leg ulcers. Cochrane Database of Syst Rev. 2016.18;2:CD009432. https://doi. org/0.1002/14651858.CD009432.pub2

18. Moscicka P, Szewczyk MT, Jawien A, Cierzniakowska K, Cwajda-Białasik J. Subjective and objective assessment of patients' compression therapy skills as a predicator of ulcer recurrence. J Clin Nurs. 2016;25(13-14):1969-76. https://doi. org/10.1111/jocn.13218 
19. Alavi A, Sibbald RG, Phillips TJ, Miller OF, Margolis DJ, Marston W, et al. What's new: management of venous leg ulcers: treating venous leg ulcers. J Am Acad Dermatol. 2016;74(4):643-64. https://doi.org/10.1016/j.jaad.2015.03.059

20. Gonzalez A. The effect of a patient education intervention on knowledge and recurrence of venous ulcer: results of a prospective intervention and retrospective analysis. Ostomy Wound Manage. 2017;63(6):16-28

21. Nelson EA, Bell-Syer SE. Compression for preventing recurrence of venous ulcers: review. Cochrane Database Syst Rev. 2014;9;(9):CD002303. https://doi. org/10.1002/14651858.CD002303.pub3

22. Edwards $H$, Courtney M, Finlayson K, Lindsay E, Lewwis $C$, Shuter $\mathrm{P}$, et al. Chronic venous leg ulcers: effect of a community nursing intervention on pain and healing.
Nurs Stand. 2005;19(52):47-54. https://doi.org/10.7748/ ns2005.09.19.52.47.c3950

23. Agência Nacional de Vigilância Sanitária. Ácido acetilsalicílico. Medicamento Genérico, Lei n²3, de 1999 [cited 20 June 2018]. Available at: http://www.anvisa.gov.br/datavisa/fila_ bula/frmVisualizarBula.asp?pNuTransacao $=9023672015 \& \mathrm{p}$ IdAnexo=2891796

24. Layton AM, Goodfield MJ, Ibbotson SH, DaviesJA. Randomised trial of oral aspirin for chronic venous leg ulcers. The Lancet. 1994;344:164-5

25. Del Río Solá ML, Antonio J, Fajardo G, Vaquero Puerta C. Influence ofaspirintherapyintheulcerassociated withchronic venous insufficiency. Ann Vasc Surg. 2012;26(5):620-9. https://doi.org/10.1016/j.avsg.2011.02.051 